QA: QA

TDR-EBS-NU-000003 REV 00

\title{
Summary of the Supplemental Model Reports Supporting the Disposal Criticality Analysis Methodology Topical Report
}

By

Douglas A. Brownson

Prepared for:

U.S. Department of Energy

Yucca Mountain Site Characterization Office

P.O. Box 364629

North Las Vegas, Nevada 89036-8629

Prepared by:

Bechtel SAIC Company, LLC

1180 Town Center Drive

Las Vegas, Nevada 89144

Under Contract Number

DE-AC08-01RW12101 


\section{DISCLAIMER}

This report was prepared as an account of work sponsored by an agency of the United States Government. Neither the United States Government nor any agency thereof, nor any of their employees, nor any of their contractors, subcontractors or their employees, makes any warranty, express or implied, or assumes any legal liability or responsibility for the accuracy, completeness, or any third party's use or the results of such use of any information, apparatus, product, or process disclosed, or represents that its use would not infringe privately owned rights. Reference herein to any specific commercial product, process, or service by trade name, trademark, manufacturer, or otherwise, does not necessarily constitute or imply its endorsement, recommendation, or favoring by the United States Government or any agency thereof or its contractors or subcontractors. The views and opinions of authors expressed herein do not necessarily state or reflect those of the United States Government or any agency thereof. 


\section{Summary of the Supplemental Model Reports Supporting the Disposal Criticality Analysis Methodology Topical Report}

TDR-EBS-NU-000003 REV 00

September 2002

Prepared by:

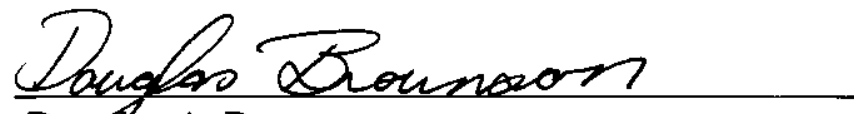

Doygras A. Brownson

Manager, Risk and Criticality Department
$9 / 26 / 02$

Date

Checked by:
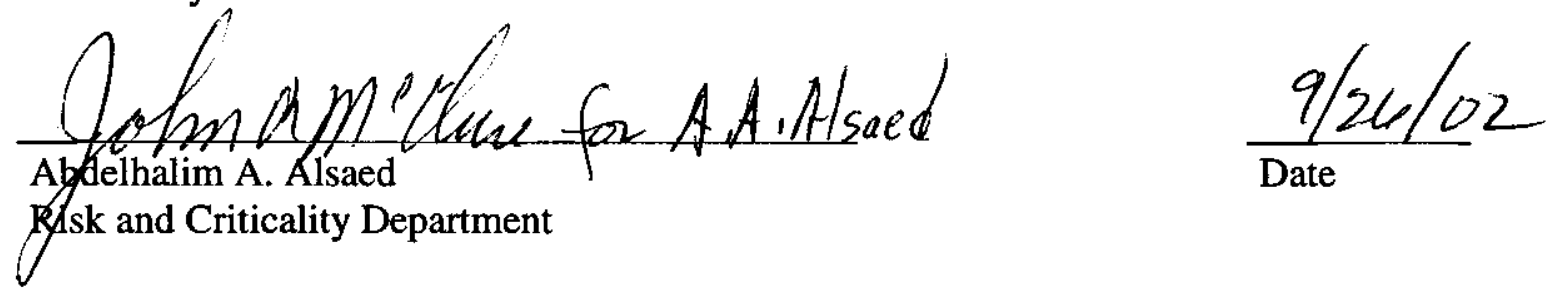

Approved by:
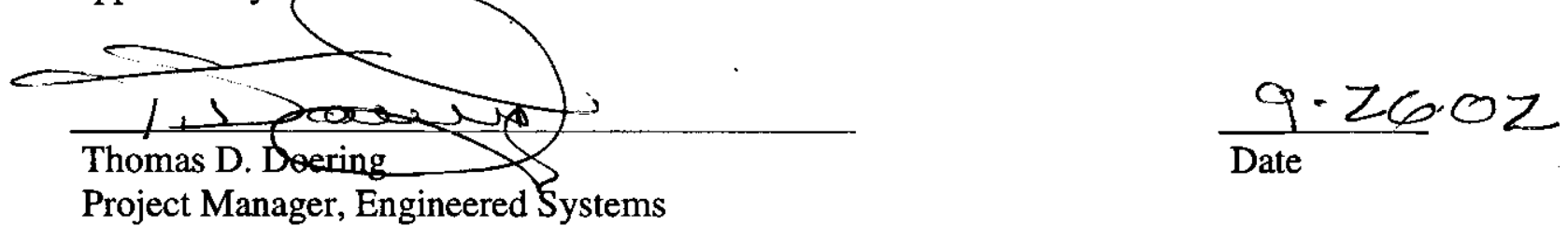

Project Manager, Engineered Systems

1. This product contains no potentially sensitive information.

2. This product contains information that could define a target.

3. This product contains information that could define a specific location.

4. This product contains information that identifies vulnerabilities. 
INTENTIONALLY LEFT BLANK 


\section{CHANGE HISTORY}

Revision Interim Effective

Number Change No. Date

00

0

Description of Change

Initial issue. 


\section{INTENTIONALLY LEFT BLANK}




\section{CONTENTS}

Page

ACRONYMS AND ABBREVIATIONS xi

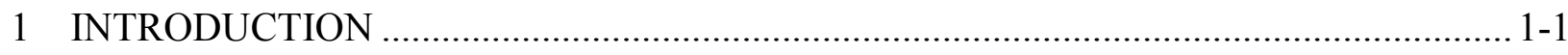

2 SUMMARY OF MODEL REPORTS .................................................................... 2-1

2.1 Model Report Development Schedule and Description........................................... 2-1

2.1.1 Geochemistry Model Validation Report: Material Degradation and Release

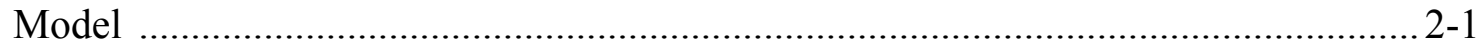

2.1.2 Geochemistry Model Validation Report: External Accumulation Model ........2-3

2.1.3 Isotopic Model Report for Commercial Spent Nuclear Fuel ........................... 2-4

2.1.4 Criticality Model Report .................................................................. 2-5

2.1.5 Criticality Model Report: External ......................................................... 2-6

2.1.6 Configuration Generator Model for In-Package Criticality............................ 2-6

2.1.7 Configuration Generator Model Report: External ...........................................2-8

2.1.8 Steady-State Criticality Consequence Model Report ....................................2-9

2.1.9 Transient Criticality Consequence Model Report....................................... 2-10

2.2 Model Reports to be Developed to Support License Application Submittal............. 2-12

2.3 Additional Model Reports to be Developed Prior to License Application

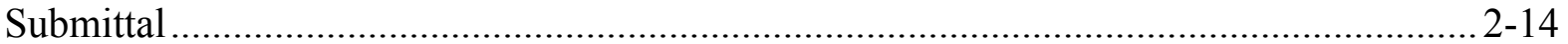

2.4 Model Reports to be Completed After License Application Submittal ..................... 2-14

2.5 Model Report Cross References .................................................................. 2-17

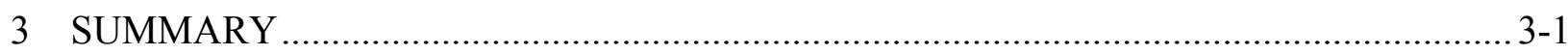

4 REFERENCES ................................................................................................. 4

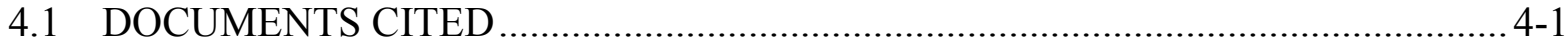

4.2 CODES, STANDARDS, REGULATIONS AND PROCEDURES ......................... 4-2

Attachment A Listing of Safety Evaluation Report Open Items ....................................... A-1

Attachment B Listing of Model Report Key Technical Issue Agreements ......................... B-1 


\section{INTENTIONALLY LEFT BLANK}




\section{TABLES}

Page

1. Listing of Model Reports Supporting the Disposal Criticality Analysis Methodology Topical Report ...................................................................................... 2-2

2. Listing of Model Reports to be Developed to Support License Application Submittal

3. Listing of Additional Model Reports to be Developed Prior to License Application Submittal to Support NRC Commitments Resulting from the Disposal Criticality Analysis Methodology Topical Report..

4. Listing of Model Reports to be Developed After License Application Submittal .........2-16

5. Model Report Cross Reference to NRC KTI Agreements, Safety Evaluation Report Open Items, and Requests for Additional Information 


\section{INTENTIONALLY LEFT BLANK}




\section{ACRONYMS AND ABBREVIATIONS}

$\begin{array}{ll}\text { BSC } & \text { Bechtel SAIC Company, LLC } \\ \text { BWR } & \text { Boiling Water Reactor } \\ \text { CL } & \text { Critical Limit } \\ \text { CSNF } & \text { Commercial Spent Nuclear Fuel } \\ \text { DOE } & \text { U.S. Department of Energy } \\ \text { EM } & \text { DOE Office of Environmental Management } \\ \text { FEPs } & \text { Features, Events, and Processes } \\ \text { GWd/mtU } & \text { Gigawatt Days Per Metric Ton Uranium } \\ \text { HLW } & \text { High Level Waste } \\ \text { keff } & \text { Effective Neutron Multiplication Factor } \\ \text { KTI } & \text { Key Technical Issue } \\ \text { NN } & \text { DOE Office of Nuclear Nonproliferation } \\ \text { NRC } & \text { U.S. Nuclear Regulatory Commission } \\ \text { OCRWM } & \text { DOE Office of Civilian Radioactive Waste Management } \\ \text { PWR } & \text { Pressurized Water Reactor } \\ \text { RW } & \text { DOE Office of Radioactive Waste } \\ & \text { Spent Nuclear Fuel } \\ \text { SNF } & \text { DO }\end{array}$




\section{INTENTIONALLY LEFT BLANK}




\section{INTRODUCTION}

The Department of Energy (DOE) Office of Civilian Radioactive Waste Management (OCRWM) has committed to a series of model reports documenting the methodology to be utilized in the Disposal Criticality Analysis Methodology Topical Report (YMP 2000). These model reports detail and provide validation of the methodology to be utilized for criticality analyses related to:

- Waste form / waste package degradation

- Waste package isotopic inventory

- Criticality potential of degraded waste form / waste package configurations (effective neutron multiplication factor)

- Probability of criticality (for each potential critical configuration as well as total event)

- Criticality consequences.

This purpose of this summary report is to provide a status of the model reports and a schedule for their completion. This report also provides information relative to the model report content and validation. The model reports and their revisions are being generated as a result of:

- Commitments made in the Disposal Criticality Analysis Methodology Topical Report (YMP 2000);

- Open Items from the Safety Evaluation Report (Reamer 2000);

- Key Technical Issue agreements made during DOE / U.S. Nuclear Regulatory Commission (NRC) Technical Exchange Meeting (Reamer and Williams 2000); and

- NRC requests for additional information (Schlueter 2002).

A comprehension of the content of Revision 1 of Disposal Criticality Analysis Methodology Topical Report (YMP 2000) is of value in understanding the information presented in this summary report.

This report has been developed to address DOE Deliverable Item PACRIT024D associated with work package P4E12234F4 (Neutronics Methodology - LA [License Application]) of work breakdown structure (WBS) 1.2.22.3.4.

This report has been developed in accordance with AP-3.11Q, Technical Reports. The technical work planning that governs the development of this report is Technical Work Plan for: Risk and Criticality Department P4E12234F4 and P4E12234FY (BSC 2002e), which was prepared per AP-2.21Q, Quality Determinations and Planning for Scientific, Engineering and Regulatory Compliance Activities. The development of this report is subject to the Quality Assurance Requirements and Descriptions (DOE 2002b) requirements. 
In addition to the requirements of AP-3.11Q and QARD, as a DOE deliverable the appropriate documentation has been prepared for submittal in accordance to Submittal, Review, and Acceptance of Deliverables, AP-7.5Q. 


\section{SUMMARY OF MODEL REPORTS}

A total of nine model reports have been scheduled to address the Disposal Criticality Analysis Methodology Topical Report (YMP 2000) commitments. Several revisions of each of these model reports are necessary to account for methodology differences related to various waste forms, criticality events internal and external to the waste package, and steady-state and transient criticality events. The various waste forms proposed for disposal at the Monitored Geologic Repository include commercial spent nuclear fuel (CSNF) - both pressurized water reactor (PWR) CSNF and boiling water reactor (BWR) CSNF; DOE spent nuclear fuel (SNF); and DOE high level waste (HLW). Naval SNF is not covered by the model reports discussed below, rather it will be addressed through the methodology presented in the Topical Report Addendum (Mowbray 1999). Originally, seventeen model reports were envisioned to be developed. This has since been reduced to nine, but their content encompasses the same material. The purpose of the model reports are as supplements to the Disposal Criticality Analysis Methodology Topical Report in that they provide the details and validation of the methodology that is outlined in it.

The information provided in Section 2.1 relates to the current list and development schedule of the model reports and provides a brief description of the postclosure criticality analysis methodology to be developed and validated in the model reports. The basis for which model reports will be developed in support of the License Application and which are to be developed after License Application is presented in Sections 2.2 through 2.4. Section 2.5 provides a crossreference between the model reports and the applicable Safety Evaluation Report Open Items, KTI Agreements, or other correspondence.

\subsection{MODEL REPORT DEVELOPMENT SCHEDULE AND DESCRIPTION}

The list of the nine model reports and their revisions is provided in Table 1. This list also includes the currently scheduled completion dates for these model reports. It should be noted that the scheduled completion dates are dependent on availability of information necessary to develop models and perform analyses, availability of resources to perform activities, and (unless otherwise specified) availability of DOE-RW (DOE Office of Radioactive Waste) funding.

A brief description of the contents of the nine model reports is provided below.

\subsubsection{Geochemistry Model Validation Report: Material Degradation and Release Model}

The Geochemistry Model Validation Report: Material Degradation and Release Model (BSC 2001c) documents the geochemistry degradation models used to evaluate the long-term geochemical behavior of the various waste form / waste package combinations proposed for disposal in the Monitored Geologic Repository. These models have been developed to predict (1) the extent to which criticality control material, such as boron or gadolinium, will remain in the waste package after initial breach of the waste package, (2) the extent to which fissile materials, such as uranium and plutonium, will be removed from the waste package, and (3) the chemical composition and amount of minerals and other solids remaining in the waste package.

Specifically, the purpose of this model report is to document the geochemistry models developed for evaluating the six criticality scenarios internal to the waste package as presented in Figures 3-2a and 3-2b of YMP 2000. Models for these six criticality scenarios are developed by 
Table 1. Listing of Model Reports Supporting the Disposal Criticality Analysis Methodology Topical Report

\begin{tabular}{|c|c|c|}
\hline Revision & Title & Scheduled Completion \\
\hline \multicolumn{3}{|c|}{ 1. Geochemistry Model Validation Report: Material Degradation and Release Model, ANL-EBS-GS-000001 } \\
\hline 0 & Flooded Waste Package Model & completed \\
\hline 1 & Film Degradation Model & December 2003 \\
\hline \multicolumn{3}{|c|}{ 2. Geochemistry Model Validation Report: External Accumulation Model, ANL-EBS-GS-000002 } \\
\hline 0 & Accumulation in Fractured Tuff Model & completed \\
\hline 1 & Accumulation in the Invert Model & May 2004 \\
\hline \multicolumn{3}{|c|}{ 3. Isotopic Model Report for Commercial Spent Nuclear Fuel, MDL-DSU-NU-000001 } \\
\hline 0 & PWR SNF & December 2002 \\
\hline 1 & BWR SNF & September 2003 \\
\hline 2 & Mixed Oxide SNF & FY05+ ${ }^{1}$ \\
\hline \multicolumn{3}{|c|}{ 4. Criticality Model Report, MDL-EBS-NU-000002 } \\
\hline 0 & PWR SNF & September 2002 \\
\hline 1 & BWR SNF & September 2003 \\
\hline 2 & DOE SNF Co-Disposal & September 2003 \\
\hline 3 & Plutonium & FY05+ ${ }^{1}$ \\
\hline 4 & Mixed Oxide SNF & FY05+ ${ }^{1}$ \\
\hline \multicolumn{2}{|c|}{ 5. Criticality Model Report: External } & FY04+ \\
\hline \multicolumn{3}{|c|}{ 6. Configuration Generator Model for In-Package Criticality, MDL-EBS-NU-000001 } \\
\hline 0 & PWR SNF & November 2002 \\
\hline 1 & BWR SNF & August 2003 \\
\hline 2 & DOE SNF Co-Disposal & FY04+ ${ }^{2}$ \\
\hline 3 & Plutonium & FY05+ ${ }^{1}$ \\
\hline 4 & Mixed Oxide SNF & FY05+ ${ }^{1}$ \\
\hline \multicolumn{3}{|c|}{ 7. Configuration Generator Model Report: External } \\
\hline 0 & Near-Field/In-Drift Configurations & FY04+ \\
\hline 1 & Far-Field Configurations & FY04+ \\
\hline \multicolumn{3}{|c|}{ 8. Steady-State Criticality Consequence Model Report } \\
\hline 0 & Internal & December 2003 \\
\hline 1 & External & FY05+ \\
\hline \multicolumn{3}{|c|}{ 9. Transient Criticality Consequence Model Report } \\
\hline 0 & Internal & May 2004 \\
\hline 1 & External & FY05+ \\
\hline
\end{tabular}

1 Dependent on the availability of DOE-EM (DOE Office of Environmental Management), DOE-NN (DOE Office of Nuclear Nonproliferation) or DOE-RW (DOE Office of Radioactive Waste) funding.

2 Dependent on the availability of DOE-EM funding. 
varying the degradation rates of the waste form and the waste package internal components over several orders of magnitude. The first three criticality scenarios are addressed in Revision 0 of this model report. These three scenarios represent a waste package fully flooded or "bathtub" condition, i.e, the waste package has a breach location near the top of the package that would allow water to accumulate and be retained within the package for a prolonged period. The waste form / waste package material degradation and release processes are represented using the EQ3/6 (CRWMS M\&O 1999a) and the EQ6 (CRWMS M\&O 1999b) software codes. An application of these models is provided for the geochemical degradation evaluation of DOE SNF co-disposal waste packages. Application of these models for other waste form / waste package combinations will be documents in separate reports. The spent fuel degradation sub-model and the high level waste glass degradation sub-model were validated by comparison of experimental and modeled results. The types of minerals formed and aqueous concentrations predicted by the model were compared to experimental results to quantify the uncertainty range of the sub-models. Changes to the sub-model inputs were identified, as necessary, to allow for a better fit of experimental to predicted results.

In Revision 1 of the Geochemistry Model Validation Report: Material Degradation and Release Model, several additional issues will be addressed. These issues are: (1) validation of a steel degradation sub-model; (2) the loss of material from the waste package by colloids or entrainment; and (3) waste package flow-through conditions in which degradation occurs within a thin film of water covering the materials. The last three internal criticality scenarios in Figures 3-2a and 3-2b of YMP 2000 will be represented by the waste package flow-through model. This model will be validated by comparison of experimental and modeled results. All three sub-models (degradation of spent fuel, high level waste glass, and steels) will be validated by comparison with results from laboratory experiments. Those variations in sub-model inputs, as identified in Revision 0 of this model report, will be incorporated into modified inputs for the material degradation and release model as a whole (with the sub-models working simultaneously). If the results of the material degradation and release model, using the modified inputs, show a fissile material loss or neutron absorber loss from the waste package that is within the range of results calculated using the standard range of inputs as defined in the report, then the model will be considered validated.

\subsubsection{Geochemistry Model Validation Report: External Accumulation Model}

The purpose of the Geochemistry Model Validation Report: External Accumulation Model (BSC 2001b) is to document the models that will be utilized to evaluate the criticality scenarios external to the waste package that are defined in Figures 3-3a and 3-3b of YMP 2000. The accumulation of fissile materials in fractures and lithophysae in the far-field are covered in Revision 0 of this model report. The primary mechanism for the accumulation of fissile material is the mixing of a high $\mathrm{pH}$, actinide-laden solution with water from outside the waste package. This process lowers the $\mathrm{pH}$ values sufficiently for fissile materials to become insoluble and precipitate. This model report also discusses alternate mechanisms that are less likely to cause significant accumulation in the far field, such as bio-accumulation, reducing zone, colloidal transport and filtering, and sorption. The waste form / waste package degradation and material 
transport and accumulation processes are represented using the EQ3/6 (CRWMS M\&O 1999a), the EQ6 (CRWMS M\&O 1999b) and the PHREEQC (BSC 2002d) software codes.

The methodology documented in the Geochemistry Model Validation Report: External Accumulation Model is consistent with the processes outlined in Section 3.4.2.1 of YMP 2000.

Validation of the models for external accumulation of fissile material is by benchmark comparison with precipitation of minerals in laboratory experiments having chemical conditions representative of the repository. An application of the models developed in Revision 0 of this model report has been included. This application represents an evaluation of the mineral phases precipitating from degrading DOE HLW glass. Results from the model evaluation matched well with the experimentally observed materials.

Revision 1 of the Geochemistry Model Validation Report: External Accumulation Model will include documentation of models to be utilized in the evaluation of fissile material accumulation in the invert. In Revision 1, the validation will be expanded from that developed in Revision 0, by refining the model inputs. Those changes will then be implemented into the external accumulation model as a whole. If the results of the external accumulation model, using the modified inputs, show an accumulation within the range of results calculated using the standard range of inputs as defined in the report, then the model will be considered validated.

\subsubsection{Isotopic Model Report for Commercial Spent Nuclear Fuel}

For CSNF, credit is sought for the reduced reactivity associated with the net depletion of fissile isotopes and the creation of neutron-absorbing isotopes during the period since nuclear fuel was first inserted into a commercial reactor. This period includes the time that the fuel was in a reactor and exposed to a high neutron flux (in a power production mode), the downtime between irradiation cycles, and the cooling time since it was permanently removed from the reactor. Taking credit for the reduced reactivity associated with this change in fuel material composition is known as burnup credit. Burnup is a measure of the amount of exposure for a nuclear fuel assembly in a power production mode, usually expressed in units of gigawatt days per metric ton of uranium $(\mathrm{GWd} / \mathrm{mtU})$ initially loaded into the assembly.

The purpose of the Isotopic Model Report for Commercial Spent Nuclear Fuel (BSC 2002c) is to estimate nuclide concentrations in CSNF waste forms at the time of emplacement and throughout the postclosure period by taking into consideration the reduced reactivity of a fuel assembly resulting from burnup credit, cooling time, the initial enrichment of fissile material in the fuel, and the availability of individual isotopes based on degradation analyses. Radiochemical assay data from both PWR and BWR CSNF will be utilized to validate the model. The quality of the correlation between calculated and measured values for individual isotopes is determined using statistical methods. MCNP (CRWMS M\&O 1998) will be used to quantify the reactivity bias in $\mathrm{k}_{\text {eff }}$ associated with the isotopic uncertainties. This integral appoach in determining the reactivity bias takes into account the isotopic uncertainties collectively without accounting for the uncertainties associated with each individual isotope. Results from evaluations using this model will be used in the criticality model for evaluating the criticality potential of the waste form configurations. 
The isotopic model utilizes a one-dimensional neutron transport calculation with point-depletion using the SAS2H module of the SCALE 4.4A software code (CRWMS M\&O 2000a). This model will be used to analyze samples of fuel pellets that have been irradiated in commercial reactors. Radiochemical assay samples are taken from several PWR and BWR fuel assemblies and cover a range of burnup and initial fuel enrichments. Burnup history parameters that affect analyses of CSNF assay samples through neutron spectral effects include power densities, moderator temperatures and densities, fuel temperatures, and soluble boron concentrations (for PWRs). This, in turn, will affect the isotopic concentrations of the fuel samples. Thus, appropriate values for these parameters will be used in the analysis of the samples for the isotopic model validation.

For design applications, two aspects of the isotopic model for CSNF must be addressed. First, values for the initial isotopic concentrations must be conservative with respect to their effect on reactivitiy. Second, changes to the initial isotopic concentration values, as a function of time for postclosure, must also be conservative with respect to their contribution towards criticality. The isotopic model seeks acceptance that the requirements for modeling burnup of CSNF for design applications, when met, are sufficient to ensure adequate conservatism in the isotopic model for burnup credit. This model report will validate the conservatism in using bounding isotopics for CSNF evaluations.

\subsubsection{Criticality Model Report}

The purpose of the Criticality Model Report (BSC 2002b) is to validate the ability of the MCNP software code (CRWMS M\&O 1998) and the cross section libraries to be used to accurately predict the effective neutron multiplication factor $\left(\mathrm{k}_{\mathrm{eff}}\right)$. A $\mathrm{k}_{\mathrm{eff}}$ is predicted for a range of conditions spanned by potentially critical degraded configurations internal to the waste packages as defined by Figures 3-2a and 3-2b of YMP 2000. A number of commercial reactor critical benchmarks and laboratory critical experiments have been identified to perform this validation. The ranges of parameters of the internal waste package configurations are extracted from the Geochemistry Model Validation Report: Material Degradation and Release Model (BSC 2001c). Results of this work are an indication of the accuracy of MCNP for calculating eigenvalues, which will be used as input for criticality analyses for waste form disposal at the Monitored Geologic Repository.

The validation approach of the internal criticality model will include:

- selection of benchmark experiments;

- calculation of the bias and uncertainty and critical limits associated with the computer codes used to calculate criticality;

- establishment of the range of applicability of the benchmark experiments; and

- the acceptance criteria for the internal criticality model.

An essential element of validating the methods and models used for calculating $\mathrm{k}_{\text {eff }}$ for a waste form is the determination of the critical limit $(C L)$. The CL is derived from the bias and 
uncertainties associated with the criticality code and modeling process. The CL for a waste form is a limiting value of $\mathrm{k}_{\mathrm{eff}}$ at which a configuration is considered potentially critical.

Five revisions to the Criticality Model Report are currently scheduled - one for each of the primary waste forms currently envisioned for disposal in the Monitored Geologic Repository. Naval SNF will be addressed through the methodology presented in the Topical Report Addendum (Mowbray 1999).

\subsubsection{Criticality Model Report: External}

The purpose of the Criticality Model Report: External is to validate the ability of the MCNP software code (CRWMS M\&O 1998) and its associated cross section libraries to accurately predict the effective neutron multiplication factor $\left(\mathrm{k}_{\mathrm{eff}}\right)$ for a range of conditions spanned by potentially critical configurations external to the waste package as defined by Figures 3-3a and 3-3b of YMP 2000. The conditions and the ranges of parameters of the external configurations are extracted from Geochemistry Model Validation Report: External Accumulation Model (BSC 2001b) and Geochemistry Model Validation Report: Material Degradation and Release Model (BSC 2001c). Results of this work are an indication of the accuracy of MCNP for calculating eigenvalues, which will be used as input for criticality analyses for the waste forms that have been identified for disposal at the Monitored Geologic Repository.

The validation approach of the external criticality model will include:

- $\quad$ selection of benchmark experiments;

- calculation of the bias and uncertainty and critical limits associated with the computer codes used to calculate criticality;

- establishment of the range of applicability of the benchmark experiments; and

- the acceptance criteria for the external criticality model.

Only one version of the Criticality Model Report: External is currently scheduled. This report is expected to encompass the methodology required for the evaluation of all waste forms currently envisioned for disposal in the Monitored Geologic Repository.

\subsubsection{Configuration Generator Model for In-Package Criticality}

The purpose of the Configuration Generator Model for In-Package Criticality (BSC 2002a) is to document the risk-informed, performance-based methodology for calculating the probability of a critical configuration internal to waste packages. This model incorporates the probability densities for all processes required for specific critical configurations and numerically integrates the equation to obtain the probability of the critical configuration. The detailed methodology presented in this model report differs from the approach identified in Section 3.6 of YMP 2000 as that approach was directed towards the development of a software system.

For the probabilistic analysis part, the configuration generator model utilizes the event tree / fault tree methodology of the SAPHIRE software code (CRWMS M\&O 2001) to express the 
degradation processes and pathways that lead to the different configurations. The construction of the event tree captures all six of the potentially critical configurations internal to the waste package as presented in Figures 3-2a and 3-2b of YMP 2000.

The event tree model begins by defining the various waste forms anticipated for disposal in the Monitored Geologic Repository. The event tree lists in sequential order the degradation processes required to reach each of the six in-package configurations. The top events on the event tree are the specific processes required for degradation. The branching under the top events (degradation processes) provides a traceable path to each configuration class. The different configuration classes are indicated as end states on the event tree.

Mathematical models used in the probabilistic analyses are density functions that define the probability of realizing rates for various processes such as but not limited to degradation and seepage. These functions are utilized as inputs into the configuration generator event tree model.

Another part of the event tree model addresses the calculation of the criticality potential for a given in-package configuration. The event tree model will be capable of evaluating the probability of achieving the various in-package configurations for the different waste form / waste package combinations. Once the potential for criticality of a given configuration has been determined, the probability of achieving that configuration needs to be evaluated. This starts with an initial criticality screening using a $\mathrm{k}_{\mathrm{eff}}$ regression analysis. The regression equations will utilize information based on the configuration class and the range of degradation parameters for the specific waste form and waste package to determine if the waste form has any potential of becoming critical. The intent of this screening analysis is to identify configurations that have no potential for criticality. A detailed $\mathrm{k}_{\text {eff }}$ evaluation using criticality codes will then be performed for configurations that cannot be screened out. If the calculated $\mathrm{k}_{\mathrm{eff}}$ from the detailed evaluation is greater than the CL, then a probability analysis will be performed (YMP 2000, Section 3.2.1) using the event tree and mathematical models discussed above.

The event probabilities for the degradation processes will be abstracted from the range of parameters required to define the configurations. Abstractions developed from various models for the configuration generator event tree model will include uncertainties in the abstraction values that can be readily incorporated into the event tree model analysis. Abstractions are used in particular for generating probability density functions for independent parameters and developing correlation equations for other variables. Because the configuration generator model is a probabilistic model, indirect validation methods are used since experimental data are not available for direct comparison with model results. The validation approach for the probabilistic structure of the configuration generator model is to perform a technical review of the process. Validation of abstraction sub-models will be through determination of the goodness of fit of the abstracted sub-models against the parent data using statistical methods to determine the quality of the fit. The current validation approach differs from the approach identified in Section 3.6 of YMP 2000 as that approach was directed toward validation of a software system.

Revisions to the Configuration Generator Model for In-Package Criticality have been scheduled to incorporate any methodology modifications that may be required to the configuration generator event tree model to account for the various waste forms. 


\subsubsection{Configuration Generator Model Report: External}

The purpose of the Configuration Generator Model Report: External is to document the riskinformed, performance-based methodology for calculating the probability of a critical configuration external to waste packages. This environment includes both the near-field (invert) adjacent to the waste package and the far-field (fractures and lithophysae) locations. This model incorporates the probability densities for all processes required for specific critical configurations and numerically integrates the equation to obtain the probability of the critical configuration. The Configuration Generator Model Report: External is concerned with the ten external configuration classes from the Master Scenario List (YMP 2000, Figures 3-3a and 3-3b). The event tree / fault tree methodology of the SAPHIRE software code (CRWMS M\&O 2001) will be utilized to define and evaluate the probability of the pathways by which the various external critical configurations may be obtained.

The probabilistic analysis proceeds in essentially the same manner as described above in the configuration generator model for internal waste package configurations except that degradation scenarios are replaced with transport and deposition scenarios. The event tree model begins by defining the various source terms and transport mechanisms anticipated in the Monitored Geologic Repository. The event tree defines in sequential order the processes required to reach each of the ten external configurations. The top events on the event tree are the specific processes required for degradation. The branching under the top events (degradation processes) provides a traceable path to each configuration class. The different configuration classes are identified as end states on the event tree.

In a similar manner as described for the internal waste package configuration generator model, part of the event tree model addresses the calculation of the criticality potential for a given endstate configuration. The event tree model will be capable of evaluating the probability of achieving the configurations for the fissile material accumulations. Once the potential for criticality of a given configuration has been determined, the probability of achieving that configuration needs to be evaluated. This will be evaluated with a detailed $\mathrm{k}_{\mathrm{eff}}$ evaluation using criticality codes. Because the configurations in the external fields cannot be readily determined in advance, preliminary $\mathrm{k}_{\mathrm{eff}}$ screening, as is performed for the internal waste package model, may not be feasible. However, detailed $\mathrm{k}_{\mathrm{eff}}$ evaluations will be performed and if greater than the CL (YMP 2000, Section 3.2.1), then a probability analysis of that external configuration will be performed using the event tree and mathematical models for the external configuration. The event probabilities for the processes will be based on the range of parameters required to achieve the potentially critical configuration.

Abstractions developed from various models for the configuration generator event tree model will include uncertainties in the abstraction values that can be readily incorporated into the event tree model analysis through sensitivity evaluations. Validation of the various models developed for Configuration Generator Model Report: External will be similar to that used in the validation of Configuration Generator Model for In-Package Criticality. 


\subsubsection{Steady-State Criticality Consequence Model Report}

Two revisions to the Steady-State Criticality Consequence Model Report are currently scheduled in order to develop the steady-state consequence methodology for criticality events both internal and external to the waste package. The following sections describe the methodology approach that is envisioned for these two different scenarios. The methodology is expected to be applicable to all waste forms.

\section{Internal Waste Package Model}

The internal steady-state methodology starts with the potential critical configurations identified from the application of the models developed in Configuration Generator Model for In-Package Criticality. The purpose of the internal steady state consequence model is to estimate the power and duration for a potential in-package criticality and the nuclide concentration adjustments resulting from such a criticality using zero-dimensional engineering methods. The modeling approach to the steady-state criticality consequence evaluation emphasizes the use of hydraulic mechanisms to couple the various processes. This approach derives from the absence of any identifiable mechanisms leading to an internal criticality event without water moderation. However, some potential critical configurations may incorporate alternate or additional moderators, such as silica from glass degradation or the host rock, which are included in the evaluation as necessary. The model will include abstracted results from validated models as well as generally accepted engineering methodology. Incremental radionuclide inventories that are the principal consequence of a steady-state criticality are evaluated using the ORIGEN-S module of the SCALE software code (CRWMS M\&O 2000a).

The principal components of the internal waste package steady-state consequence model documentation are as follows:

- characterization of neutron moderation (presence of water and the rate of water ingress or the presence of non-hydrogenous moderators [silica]) derived from seepage rate abstractions from the internal configuration generator model (BSC 2002a);

- characterization of the waste form criticality parameters;

- abstraction of the mass transport rate (accumulation and loss) of thermally fissionable material and neutron absorber materials using the mass transport and loss model;

- calculation of the energy balance during the steady-state criticality event (reactivity feedback effects) evaluated using the MCNP and SCALE software codes (CRWMS M\&O 1998 and CRWMS M\&O 2000a, respectively);

- characterization of the thermal effects resulting from the criticality event on seepage rate;

- characterization of thermally enhanced corrosion and nuclide transport and radiolytic enhanced corrosion internal to the waste package as well as on adjacent waste package surfaces; 
- quantification of the increased radionuclide inventory resulting from an in-package criticality event; and

- validation of the model as described in Section 3.7.3.1 of YMP 2000.

\section{External Waste Package Model}

The external steady-state methodology starts with the potential critical configurations identified from the application of the models developed in Configuration Generator Model Report: External. The purpose of the external steady-state consequence model is to estimate the power and duration for a criticality and the nuclide concentration increments resulting from such a criticality using a zero-dimensional model. The steady-state consequence model for external environments is similar in concept to the internal steady-state model with abstractions and engineering methods adapted to the external environment. Hydraulic mechanisms coupled with thermal effects that affect external critical configurations include the saturation level of the surrounding environment and net seepage flow through the volume. Seepage flow sources include outflow from the waste packages as well as from the drift region exterior to the waste package. Incremental radionuclide inventories that are the principal consequence of a steadystate criticality are evaluated with the ORIGEN-S module of the SCALE software code (CRWMS M\&O 2000a). The principal contents of the external steady-state consequence model documentation are as follows:

- characterization of the fissionable material configuration in the near-field (invert) or the far-field (fractures and lithophysae) as defined by the results from the external configuration generator model analyses;

- characterization of neutron moderation by saturation level of tuff and fractures and the presence of non-hydrogenous moderators (e.g., silica);

- characterization of criticality parameters;

- abstraction of the mass transport rate (accumulation and loss) of thermally fissionable material and the neutron absorber materials in the critical volume;

- calculation of the energy balance during criticality and evaluate effects on the system variables such as seepage flow rate and moderator loss;

- calculation of the reactivity feedback effects;

- quantification of the increased radionuclide inventory resulting from an external criticality event; and

- validation of the model as described in Section 3.7.3.1 of YMP 2000.

\subsubsection{Transient Criticality Consequence Model Report}

Two revisions to the Transient Criticality Consequence Model Report are currently scheduled in order to develop the transient consequence methodology for criticality events both internal and 
external to the waste package. The following sections describe the methodology approach that is envisioned for these two different scenarios. The methodology is expected to be applicable to all waste forms.

\section{Internal Waste Package Model}

The internal transient methodology starts with the potential configurations identified from the application of the models developed in Configuration Generator Model for In-Package Criticality. The purpose of the internal transient consequence model is to estimate the power and duration for a criticality and, to a lesser extent, the nuclide concentration increments resulting from such a criticality and the potential for any mechanical disruptions. The methodology evaluates the evolution and consequences of criticality events that span a relatively short time period. The reactivity insertion rate is determined by the response of the internal waste package configuration to (usually external) initiating events. Such events may include, but are not limited to, seismic shaking, rock fall, or volcanism. The more rapid reactivity insertion mechanism might typically have a duration of approximately 0.3 seconds (the time it might take to fall a short distance). The methodology utilizes the RELAP5 software code (CRWMS M\&O 1999c) for the transient criticality evaluation and the ORIGEN-S module of the SCALE software code (CRWMS M\&O 2000a).

There is no primary consequence measure for a transient criticality event. The incremental increase in radionuclide inventory is a factor but mechanical effects related to elevated pressures and temperatures during the event are also considered in the model. Thus, all parameters directly related to potential damage (to waste package barriers or SNF cladding) are included in the transient criticality consequence evaluation. Due to the short duration of transient criticality events, the maximum incremental radionuclide inventories from such events are much smaller than can potentially be generated from low power static events.

The increase in the radionuclide inventory following a transient criticality event is computed with ORIGEN-S by representing the incremental burnup that would be accrued during the transient criticality event, given an initial isotopic inventory at the point in time when the criticality event is assumed to occur. The initial radionuclide inventory (which is derived from the geochemical degradation and transport analyses) is also the basis for evaluating the reactivity parameters.

Transient criticality consequences associated with mechanical effects are evaluated relative to material failure criteria (i.e., yield strength) of the waste package. Mechanical effects from transient criticality events are a direct result of the pressure and temperature cycling leading to material failures that could possibly enhance the fraction of the radionuclide inventory available for transport. Consequences associated with the elevated thermal environment resulting from the transient criticality event will also be evaluated.

The revision of the Transient Criticality Consequence Model Report for in-package criticality events will include validation of the methodology based on comparisons to experimental test results. However, there are no direct natural analogs or experiments which exactly mimic the geometry and parameter ranges expected for repository configurations for these hypothetical transient events. Thus, the validation approach will be to use comparisons with representative 
experiments or incidents that cover subsets of the transient conditions that are predicted to be possible in the repository. Taken together, these subsets are expected to cover the range of actual conditions and parameter values necessary to achieve these critical configurations. The validation process for the transient consequence model is described in Section 3.7.3.2 of YMP 2000.

\section{External Waste Package Model}

The external transient methodology starts with the potential critical configurations identified from the application of the models developed in Configuration Generator Model Report: External. The purpose of the external transient consequence model is to estimate the duration, total power release and, to a lesser extent, radionuclide inventory increase that may result from a criticality event external to the waste package. The revision of the Transient Criticality Consequence Model Report for external criticality events will develop and document the models to be used for evaluating such events, establish the range of applicability for the models, and address any biases and uncertainties associated with the models. It is proposed to utilize the CECT-THX software code (to be developed) to evaluate the potential consequences of transient criticality events and the ORIGEN-S module of the SCALE software code (CRWMS M\&O 2000a) to evaluate the incremental nuclide inventory that may result from an external transient criticality event.

There is no single consequence measure for an external transient criticality event. The incremental increase in radionuclide inventory is a factor for transient criticality, although incremental production is likely to be significantly lower than for steady-state criticality for a comparable configuration. However, mechanical effects from locally elevated pressures and temperatures in the reaction-zone must also be considered for transient criticality events. Thus, all parameters directly related to potential damage and increased radionuclide inventory to the repository will be considered in the external transient criticality consequence evaluation. However, due to the short duration of transient criticality events, the maximum incremental radionuclide inventories from such events are much smaller than can potentially be generated from low power static events.

The external transient criticality model simulates the dynamics of coupled nuclear and physical processes for systems that contain fissile material, rock and neutron moderator materials. The validation process for the external transient consequence model is described in Section 3.7.3.2 of YMP 2000.

\subsection{MODEL REPORTS TO BE DEVELOPED TO SUPPORT LICENSE APPLICATION SUBMITTAL}

Although it is expected that a majority of the scheduled nine model reports and their revisions will be completed prior to License Application submittal, it is not planned that all of the identified model reports and their revisions from Table 1 will be completed. The philosophy for postclosure criticality evaluations for License Application submittal is for a demonstration of the methodology approaches outlined in YMP 2000 and not for criticality evaluations of all waste form / waste package combinations. Specific details of the methodology approaches outlined in 
YMP 2000 are to be provided in the model reports that have been and are to be generated in support of this reference.

The postclosure criticality methodology is to be demonstrated through the application of the model report methodology to the PWR CSNF waste form, specifically as it relates to the 21-PWR Absorber Plate Waste Package design. The rationale for choosing the waste form / waste package combination is that, according to Table 3-3 of the Yucca Mountain Science and Engineering Report (DOE 2002a), the 21-PWR Absorber Plate Waste Package represents approximately $55 \%$ of the 70,000 metric tons of heavy metal anticipated to be available for disposal at the Monitored Geologic Repository. Additionally, most postclosure criticality evaluations performed to date have been of this waste form / waste package combination.

Although not viewed as being necessary for the demonstration of the methodology for License Application, if sufficient resources exist, and sufficient time is available, the BWR CSNF may also be included in the License Application submittal. Specifically, the 44-BWR Waste Package design would be analyzed as this waste package design represents an additional $32 \%$ of the anticipated 70,000 metric tons of heavy metal (Table 3-3, DOE 2002a). Together, these two waste form / waste package design combinations represent $87 \%$ of the anticipated disposal waste.

Demonstration of the postclosure criticality methodology to support the License Application submittal for both PWR and BWR CSNF will require the development of the model reports and their revisions listed in Table 2.

Table 2. Listing of Model Reports to be Developed to Support License Application Submittal

\begin{tabular}{|c|c|c|}
\hline Revision & Title & Scheduled Completion \\
\hline \multicolumn{3}{|c|}{ 1. Geochemistry Model Validation Report: Material Degradation and Release Model, ANL-EBS-GS-000001 } \\
\hline 0 & Flooded Waste Package Model & completed \\
\hline \multicolumn{3}{|c|}{ 2. Isotopic Model Report for Commercial Spent Nuclear Fuel, MDL-DSU-NU-000001 } \\
\hline 0 & PWR SNF & December 2002 \\
\hline 1 & BWR SNF & September 2003 \\
\hline \multicolumn{3}{|c|}{ 3. Criticality Model Report, MDL-EBS-NU-000002 } \\
\hline 0 & PWR SNF & September 2002 \\
\hline 1 & BWR SNF & September 2003 \\
\hline \multicolumn{3}{|c|}{ 4. Configuration Generator Model for In-Package Criticality, MDL-EBS-NU-000001 } \\
\hline 0 & PWR SNF & November 2002 \\
\hline 1 & BWR SNF & August 2003 \\
\hline
\end{tabular}


Development of these revisions to the model reports will allow for the development of the postclosure criticality methodology that is required to perform the initial criticality FEPs (Features, Events, and Processes) screening analysis as required by 10 CFR 63.114(d) (10 CFR 63). This regulatory requirement states that "only events that have at least one chance in 10,000 of occurring over 10,000 years" need be considered. This requirement allows for criticality to be screened out and not included in the Total System Performance Assessment if the total probability of criticality (sum of the probabilities for all potential criticality events for all waste forms) can be demonstrated to be less than one chance in 10,000 over the 10,000-year regulatory period.

The criticality FEPs screening analysis will be performed utilizing the models developed in the Configuration Generator Model for In-Package Criticality. The other four model reports and their revisions listed in Table 2 are required to allow for the development of the configuration generator model and its supporting inputs.

\subsection{ADDITIONAL MODEL REPORTS TO BE DEVELOPED PRIOR TO LICENSE APPLICATION SUBMITTAL}

It is desirable that the additional model reports identified in Table 3 be completed prior to License Application submittal. The rationale for completing these model reports is (a) to satisfy DOE Commitments to the NRC for the completion of these documents and (b) to have established the criticality consequence methodology in the unlikely event that criticality is estimated to have a total probability greater than one chance in 10,000 of occurring over 10,000 years.

In addition to the development of the steady state and transient consequence model reports, the National Spent Nuclear Fuel Program has expressed their desire to have the DOE SNF revisions to the Criticality and Configuration Generator Model Reports completed prior to the submittal of the License Application.

\subsection{MODEL REPORTS TO BE COMPLETED AFTER LICENSE APPLICATION SUBMITTAL}

Although it is expected that a majority of the scheduled nine model reports and their revisions will be completed prior to License Application submittal, it is not planned that all of the identified model reports and their revisions from Table 1 will be completed. In particular, model reports and model report revisions dealing with external criticality and some waste forms (e.g., plutonium and mixed oxide) are not scheduled to be included in the License Application submittal. These model reports and model report revisions are identified in Table 4.

The rationale for not developing the model reports and revisions dealing with the potential for a criticality event external to the waste package is that external criticality is believed to be a postregulatory period event (i.e., beyond 10,000 years) and, therefore, unnecessary for the support of a License Application submittal. The basis for this statement is that early waste package failures

are not expected to occur during the regulatory period. This is based on the Total System Performance Assessment for the Site Recommendation (CRWMS M\&O 2000b, Section 3.4.3, p. 3-92) estimation of initial waste package failure at approximately 40,000 years. 
Table 3. Listing of Additional Model Reports to be Developed Prior to License Application Submittal to Support NRC Commitments Resulting from the Disposal Criticality Analysis Methodology Topical Report

\begin{tabular}{|c|c|c|}
\hline Revision & \multicolumn{1}{|c|}{ Title } & Scheduled Completion \\
\hline 1. Geochemistry Model Validation Report: Material Degradation and Release Model, ANL-EBS-GS-000001 \\
\hline 1 & Film Degradation Model & December 2003 \\
\hline 2. Geochemistry Model Validation Report: External Accumulation Model, ANL-EBS-GS-000002 \\
\hline 0 & Accumulation in Fractured Tuff Model & completed \\
\hline 3. Criticality Model Report, MDL-EBS-NU-000002 & September 2003 \\
\hline 2 & DOE SNF Co-Disposal & FY04+ 1 \\
\hline 4. Configuration Generator Model for In-Package Criticality, MDL-EBS-NU-000001 \\
\hline 2 & DOE SNF Co-Disposal & December 2003 \\
\hline 5. Steady-State Criticality Consequence Model Report & May 2004 \\
\hline 0 & Internal & \\
\hline 6. Transient Criticality Consequence Model Report & Internal \\
\hline \multicolumn{2}{|c|}{0} \\
\hline
\end{tabular}

The rationale for not developing the model reports and revisions dealing with the potential for a criticality event external to the waste package is that external criticality is believed to be a postregulatory period event (i.e., beyond 10,000 years) and, therefore, unnecessary for the support of a License Application submittal. The basis for this statement is that early waste package failures are not expected to occur during the regulatory period. This is based on the Total System Performance Assessment for the Site Recommendation (CRWMS M\&O 2000b, Section 3.4.3, p. 3-92) estimation of initial waste package failure at approximately 40,000 years.

Although the nominal case total system performance assessment of the Yucca Mountain Preliminary Site Suitability Evaluation includes the prediction of early waste package failures (DOE 2001, Section 3.1.2, p. 3-11), the scenario by which these failures are achieved is overly conservative for criticality considerations. This scenario assumes an improper heat treatment of the waste package closure weld results in the "failure of both the inner and outer Alloy 22 lids and the stainless steel inner lid." This assumption was made "To ensure that the potential consequences of early waste package failure is treated conservatively".

However, according to FY01 Supplemental Science and Performance Analyses (BSC 2001a, Section 7.3.6), this early waste package failure scenario is considered non-mechanistic "... because only the weld region of the outer-lid of the outer barrier would be affected by potential improper heat treatments during the stress mitigation heat treatment (e.g., induction annealing), and the inner-lid of the outer barrier is not likely affected." The purpose of this overly conservative early waste package failure scenario was to estimate the dose increase that may 
Table 4. Listing of Model Reports to be Developed After License Application Submittal

\begin{tabular}{|c|c|c|}
\hline Revision & Title & Scheduled Completion \\
\hline \multicolumn{3}{|c|}{ 1. Geochemistry Model Validation Report: External Accumulation Model, ANL-EBS-GS-000002 } \\
\hline 1 & Accumulation in the Invert Model & May 2004 \\
\hline \multicolumn{3}{|c|}{ 2. Isotopic Model Report for Commercial Spent Nuclear Fuel, MDL-DSU-NU-000001 } \\
\hline 2 & Mixed Oxide SNF & FY05+ ${ }^{1}$ \\
\hline \multicolumn{3}{|c|}{ 3. Criticality Model Report, MDL-EBS-NU-000002 } \\
\hline 3 & Plutonium & FY05+ ${ }^{1}$ \\
\hline 4 & Mixed Oxide SNF & FY05+ ${ }^{1}$ \\
\hline \multicolumn{2}{|c|}{ 4. Criticality Model Report: External } & FY04+ \\
\hline \multicolumn{3}{|c|}{ 5. Configuration Generator Model for In-Package Criticality, MDL-EBS-NU-000001 } \\
\hline 3 & Plutonium & FY05+ ${ }^{1}$ \\
\hline 4 & Mixed Oxide SNF & $\mathrm{FY} 0+^{+}{ }^{1}$ \\
\hline \multicolumn{3}{|c|}{ 6. Configuration Generator Model Report: External } \\
\hline 0 & Near-Field/In-Drift Configurations & FY04+ \\
\hline 1 & Far-Field Configurations & FY04+ \\
\hline \multicolumn{3}{|c|}{ 7. Steady-State Criticality Consequence Model Report } \\
\hline 1 & External & FY05+ \\
\hline \multicolumn{3}{|c|}{ 8. Transient Criticality Consequence Model Report } \\
\hline 1 & External & FY05+ \\
\hline
\end{tabular}

1 Dependent on the availability of DOE-EM, DOE-NN, or DOE-RW funding.

result from early failure of the waste package. The Disposal Criticality Analysis Methodology Topical Report (YMP 2000) does not consider non-mechanistic failure scenarios.

If a no early waste package failure scenario is utilized as was documented in CRWMS M\&O $2000 \mathrm{~b}$, there would be no ingress of water into the waste package, no degradation of the waste forms and, thus, no transport of fissionable material to the near-field or the far-field environments during the regulatory period.

For the model report revisions dealing with specific waste forms such as plutonium and mixed oxide, these reports have not been scheduled prior to License Application submittal because insufficient information currently exists about these waste forms to allow for an adequate evaluation of their criticality potential. As detailed information becomes available for these waste forms, model report revisions will be scheduled to account for any methodology modifications necessary for their evaluation. In addition, it is expected that it will be necessary to schedule other model report revisions for waste forms not yet identified. 
It should be cautioned, however, that the identification and evaluation of any new waste form has the potential to increase the total probability of criticality above the regulatory threshold established by 10 CFR 63.114(d). Once this regulatory threshold is exceeded, criticality consequence evaluations will be required as well as the development of a criticality model for inclusion and evaluation in the Total System Performance Assessment. This is required to compare any increase in radiological dose resulting from any potential criticality events against the regulatory dose threshold.

\subsection{MODEL REPORT CROSS REFERENCES}

This sections provide a cross reference of the model reports to the applicable Open Items from the Safety Evaluation Report (Reamer 2000), KTI Agreements made during DOE / NRC Technical Exchange Meetings (Reamer and Williams 2000), and NRC requests for additional information (Schlueter 2002).

Twenty-eight Open Items were presented in the Safety Evaluation Report (Reamer 2000). All but three of these Open Items (1, 3, and 28) are directly addressed in one or more of the model reports or one of their revisions. A listing of these Safety Evaluation Report Open Items is provided in Attachment A.

Three KTI Agreements are specifically related to the completion and delivery of the model reports to the NRC. These KTI Agreements are CLST 5.04, ENFE 5.03 and RT 4.03. A listing of the text of these KTI Agreements is provided in Attachment B. The fulfillment of a fourth KTI Agreement, CLST 5.03, is dependent on the completion of the configuration generator methodology and its application as documented in the Criticality FEPs Screening Analysis (to be developed).

A third source of model report cross-reference is through NRC requests for additional information. To date, only one letter has been issued requesting further information on the model reports (Schlueter 2002). This letter requested additional information of the two geochemistry model reports based on NRC's review of their initial revision.

Table 5. Model Report Cross Reference to NRC KTI Agreements, Safety Evaluation Report Open Items and Requests for Additional Information

\begin{tabular}{|c|l|c|c|c|}
\hline Revision & Title & KTI & Open Item & RAl \\
\hline 1. Geochemistry Model Validation Report: Material Degradation and Release Model, ANL-EBS-GS-000001 \\
\hline 0 & Flooded Waste Package Model & $\begin{array}{c}\text { CLST 5.04 } \\
\text { ENFE 5.03 } \\
\text { RT 4.03 }\end{array}$ & $12,14,17$ & $\begin{array}{c}\text { Schlueter } \\
2002\end{array}$ \\
\hline \multirow{2}{*}{1} & Film Degradation Model & $\begin{array}{c}\text { CLST 5.04 } \\
\text { ENFE 5.03 } \\
\text { RT 4.03 }\end{array}$ & $12,14,17$ & $\begin{array}{c}\text { Schlueter } \\
2002\end{array}$ \\
\hline
\end{tabular}


Table 5. Model Report Cross Reference to NRC KTI Agreements, Safety Evaluation Report Open Items and Requests for Additional Information (continued)

\begin{tabular}{|c|c|c|c|c|}
\hline Revision & Title & KTI & Open Item & RAl \\
\hline \multicolumn{5}{|c|}{ 2. Geochemistry Model Validation Report: External Accumulation Model, ANL-EBS-GS-000002 } \\
\hline 0 & Accumulation in Fractured Tuff Model & $\begin{array}{c}\text { CLST } 5.04 \\
\text { ENFE } 5.03 \\
\text { RT } 4.03\end{array}$ & $12,14,17$ & $\begin{array}{l}\text { Schlueter } \\
2002\end{array}$ \\
\hline 1 & Accumulation in the Invert Model & $\begin{array}{c}\text { CLST } 5.04 \\
\text { ENFE } 5.03 \\
\text { RT } 4.03\end{array}$ & $12,14,17$ & $\begin{array}{l}\text { Schlueter } \\
2002\end{array}$ \\
\hline \multicolumn{5}{|c|}{ 3. Isotopic Model Report for Commercial Spent Nuclear Fuel, MDL-DSU-NU-000001 } \\
\hline 0 & PWR SNF & CLST 5.04 & $\begin{array}{c}11,12,14 \\
15,17\end{array}$ & \\
\hline 1 & BWR SNF & CLST 5.04 & $\begin{array}{c}11,12,14 \\
15,17\end{array}$ & \\
\hline 2 & Mixed Oxide SNF & & $\begin{array}{c}11,12,14 \\
15,17\end{array}$ & \\
\hline \multicolumn{5}{|c|}{ 4. Criticality Model Report, MDL-EBS-NU-000002 } \\
\hline 0 & PWR SNF & CLST 5.04 & $\begin{array}{c}5,6,7,8 \\
10,12,13 \\
14,17\end{array}$ & \\
\hline 1 & BWR SNF & CLST 5.04 & $\begin{array}{c}5,6,7,8 \\
10,12,13 \\
14,17\end{array}$ & \\
\hline 2 & DOE SNF Co-Disposal & CLST 5.04 & $\begin{array}{c}5,6,7,8 \\
10,12,13 \\
14,17\end{array}$ & \\
\hline 3 & Plutonium & CLST 5.04 & $\begin{array}{c}5,6,7,8 \\
10,12,13 \\
14,17\end{array}$ & \\
\hline 4 & Mixed Oxide SNF & & $\begin{array}{c}5,6,7,8 \\
10,12,13 \\
14,17\end{array}$ & \\
\hline \multicolumn{2}{|c|}{ 5. Criticality Model Report: External } & $\begin{array}{c}\text { CLST } 5.04 \\
\text { ENFE } 5.03 \\
\text { RT } 4.03\end{array}$ & $\begin{array}{c}5,6,7,8 \\
10,12,13 \\
14,16,17\end{array}$ & \\
\hline \multicolumn{5}{|c|}{ 6. Configuration Generator Model for In-Package Criticality, MDL-EBS-NU-000001 ${ }^{1}$} \\
\hline 0 & PWR SNF & CLST 5.04 & $\begin{array}{c}4,5,9,12 \\
14,17,18 \\
19\end{array}$ & \\
\hline
\end{tabular}


Table 5. Model Report Cross Reference to NRC KTI Agreements, Safety Evaluation Report Open Items and Requests for Additional Information (continued)

\begin{tabular}{|c|c|c|c|c|}
\hline Revision & Title & KTI & Open Item & RAI \\
\hline \multicolumn{5}{|c|}{ 6. Configuration Generator Model for In-Package Criticality (continued) } \\
\hline 1 & BWR SNF & CLST 5.04 & $\begin{array}{c}4,5,9,12 \\
14,17,18 \\
19\end{array}$ & \\
\hline 2 & DOE SNF Co-Disposal & CLST 5.04 & $\begin{array}{c}4,5,9,12 \\
14,17,18 \\
19\end{array}$ & \\
\hline 3 & Plutonium & CLST 5.04 & $\begin{array}{c}12,14,17 \\
18,19\end{array}$ & \\
\hline 4 & Mixed Oxide SNF & & $\begin{array}{c}4,5,9,12 \\
14,17,18 \\
19\end{array}$ & \\
\hline \multicolumn{5}{|c|}{ 7. Configuration Generator Model Report: External } \\
\hline 0 & Near-Field/In-Drift Configurations & $\begin{array}{c}\text { CLST } 5.04 \\
\text { ENFE } 5.03 \\
\text { RT } 4.03\end{array}$ & $\begin{array}{c}12,14,16 \\
17,18,19\end{array}$ & \\
\hline 1 & Far-Field Configurations & $\begin{array}{c}\text { CLST } 5.04 \\
\text { ENFE } 5.03 \\
\text { RT } 4.03\end{array}$ & $\begin{array}{c}12,14,16 \\
17,18,19\end{array}$ & \\
\hline \multicolumn{5}{|c|}{ 8. Steady-State Criticality Consequence Model Report } \\
\hline 0 & Internal & CLST 5.04 & $\begin{array}{c}12,14,17 \\
20,21,22 \\
26\end{array}$ & \\
\hline 1 & External & $\begin{array}{c}\text { CLST } 5.04 \\
\text { ENFE } 5.03 \\
\text { RT } 4.03\end{array}$ & $\begin{array}{c}2,12,14 \\
16,17,20 \\
21,22,23 \\
26\end{array}$ & \\
\hline \multicolumn{5}{|c|}{ 9. Transient Criticality Consequence Model Report } \\
\hline 0 & Internal & CLST 5.04 & $\begin{array}{c}2,12,14 \\
16,17,24 \\
25,27\end{array}$ & \\
\hline 1 & External & $\begin{array}{c}\text { CLST } 5.04 \\
\text { ENFE } 5.03 \\
\text { RT } 4.03\end{array}$ & $\begin{array}{c}2,12,14 \\
16,17,24 \\
25,27\end{array}$ & \\
\hline
\end{tabular}

1 The methodology developed in the internal and, if necessary, the external Configuration Generator Model Reports will be utilized in developing the criticality FEPs screening analysis. Completion of this analysis is necessary to fulfill the commitments of KTI Agreement CLST 5.03. 


\section{SUMMARY}

This summary report provides information relative to the model reports being developed to satisfy commitments made in YMP 2000 to provide the details and validation of the postclosure criticality analysis methodology. Nine individual model reports, some with numerous revisions, are currently scheduled for development. In addition, these reports, considered as supplements to YMP 2000, address 25 of the 28 Open Items from the Safety Evaluation Report (Reamer 2000). Completion of these model reports will also satisfy several KTI Agreements (Reamer and Williams 2000)

The approach to the License Application for postclosure criticality described in this summary report represents an alternative approach to that originally considered at the time YMP 2000 was issued. The purpose of this alternative approach is threefold the first of which is to complete only the portion of the model reports necessary for the adequate demonstration of the criticality methodology utilizing the 21-PWR waste form / waste package combination. Secondly this alternative approach recognizes the low probability of criticality such that the screening out of criticality is likely and if demonstrated then any consequence evaluations are not required to be performed for License Application consistent with the requirements outlined in 10 CFR 63.114(d). Finally, if early waste package failure is not considered a realistic mechanism for waste package breach during the postclosure period, criticality events external to the waste package need not be considered.

These alternative approaches were adopted because they are viewed sufficient for an License Application work scope pertaining to criticality and completion of the entire suite of model reports committed to in YMP 2000 was viewed to be not only extremely arduous to complete in the License Application timeframe proposed but unnecessary. The full set of model validation reports as presented herein are, at this time planned and considered valuable to having a complete criticality methodology to potentially be used for time to peak dose efforts (beyond the regulatory period) as well as defense in depth if the screening out of criticality is not achieved, and potentially as a possible aid in addressing RAIs from the NRC during the licensing proceedings.

This summary report has also identified and presented additional changes to the methodology as originally described in YMP 2000, the most substantial of which is the use of SAPHIRE software code (CRWMS M\&O 2001) in the configuration generator model for the determination of the total probability of criticality.

In summary, it is believed a viable and defensible postclosure criticality analysis methodology utilizing model reports described herein in combination with YMP 2000 has been adopted and is sufficient for addressing the potential for postclosure criticality for the License Application submittal. 


\section{REFERENCES}

\subsection{DOCUMENTS CITED}

BSC (Bechtel SAIC Company) 2001a. FY 01 Supplemental Science and Performance Analyses, Volume 1: Scientific Bases and Analyses. TDR-MGR-MD-000007 REV 00 ICN 01. Las Vegas, Nevada: Bechtel SAIC Company. ACC: MOL.20010801.0404; MOL.20010712.0062; MOL.20010815.0001.

BSC 2001b. Geochemistry Model Validation Report: External Accumulation Model. ANLEBS-GS-000002 REV 00. Las Vegas, Nevada: Bechtel SAIC Company. ACC:

MOL.20011008.0005.

BSC 2001c. Geochemistry Model Validation Report: Material Degradation and Release Model. ANL-EBS-GS-000001 REV 00. Las Vegas, Nevada: Bechtel SAIC Company. ACC: MOL.20011017.0091.

BSC 2002a. Configuration Generator Model for In-Package Criticality MDL-EBS-NU-000001 REV 00. Las Vegas, Nevada: Bechtel SAIC Company. (DRAFT - to be issued).

BSC 2002b. Criticality Model Report. MDL-EBS-NU-000002 REV 00. Las Vegas, Nevada: Bechtel SAIC Company. (DRAFT - to be issued).

BSC 2002c. Isotopic Model Report for Commercial Spent Nuclear Fuel. MDL-EBS-NU000001 REV 00. Las Vegas, Nevada: Bechtel SAIC Company. (DRAFT - to be issued).

BSC 2002d. Software Code: PHREEQC. V2.3. PC. 10068-2.3-01.

BSC 2002e. Technical Work Plan for: Risk and Criticality Department P4E12234F4 and P4E12234FY. TWP-EBS-MD-000013 REV 00. Las Vegas, Nevada: Bechtel SAIC Company. ACC: MOL.20020611.0309.

CRWMS M\&O 1998. Software Code: MCNP. 4B2LV. HP. 30033 V4B2LV.

CRWMS M\&O 1999a. Software Code: EQ3/6. V7.2b. UCRL-MA-110662 (LSCR198).

CRWMS M\&O 1999b. Software Code: EQ6, Version 7.2bLV. V7.2bLV. 10075-7.2bLV-00.

CRWMS M\&O 1999c. Software Code: RELAP5/MOD3.2. V 1.0. STN: 100911.000.

CRWMS M\&O 2000a. Software Code: SCALE. V4.4A. HP. 10129-4.4A-00.

CRWMS M\&O 2000b. Total System Performance Assessment for the Site Recommendation. TDR-WIS-PA-000001 REV 00 ICN 01. Las Vegas, Nevada: CRWMS M\&O. ACC: MOL.20001220.0045.

CRWMS M\&O 2001. Software Code: SAPHIRE. V6.69. PC. 10325-6.69-00. 
DOE (U.S. Department of Energy) 2001. Yucca Mountain Preliminary Site Suitability Evaluation. DOE/RW-0540. [Washington, D.C.]: U.S. Department of Energy, Office of Civilian Radioactive Waste Management. ACC: MOL.20011101.0082.

DOE 2002a. Yucca Mountain Science and Engineering Report. DOE/RW-0539, Rev. 1. Washington, D.C.: U.S. Department of Energy, Office of Civilian Radioactive Waste Management. ACC: MOL.20020404.0042

Mowbray, G.E. 1999. Transmittal of the Naval Nuclear Propulsion Program Addendum to the Yucca Mountain Site Characterization Office "Disposal Criticality Analysis Methodology Topical Report." Letter from G.E. Mowbray (Department of the Navy) to C.W. Reamer (NRC), October 29, 1999. ACC: MOL.20000316.0531.

Reamer, C.W. 2000. "Safety Evaluation Report for Disposal Criticality Analysis Methodology Topical Report, Revision 0." Letter from C.W. Reamer (NRC) to S.J. Brocoum (DOE/YMSCO), June 26, 2000, with enclosure. ACC: MOL.20000919.0157.

Reamer, C.W. and Williams, D.R. 2000. Summary Highlights of NRC/DOE Technical Exchange and Management Meeting on Radionuclide Transport. Meeting held December 5-7, 2000, Berkeley, California. Washington, D.C.: U.S. Nuclear Regulatory Commission. ACC: MOL.20010117.0063.

Schlueter, J. 2002. "Key Technical Issue Agreements Related to Criticality" Letter from J. Schlueter (NRC) to S. J. Brocoum (DOE/YMSCO), February 14, 2002, with enclosure. ACC: MOL.20020607.0085.

YMP (Yucca Mountain Site Characterization Project) 2000. Disposal Criticality Analysis Methodology Topical Report. YMP/TR-004Q, Rev. 01. Las Vegas, Nevada: Yucca Mountain Site Characterization Office. ACC: MOL.20001214.0001.

\subsection{CODES, STANDARDS, REGULATIONS AND PROCEDURES}

10 CFR 63. Energy: Disposal of High-Level Radioactive Wastes in a Geologic Repository at Yucca Mountain, Nevada. Readily available.

AP-3.11Q, Rev. 3, ICN 2. Technical Reports. Washington, D.C.: U.S. Department of Energy, Office of Civilian Radioactive Waste Management. ACC: MOL.20020701.0189.

AP-7.5Q, Rev. 1, ICN 0. Submittal, Review, and Acceptance of Deliverables. Washington, D.C.: U.S. Department of Energy, Office of Civilian Radioactive Waste Management. ACC: MOL.20020701.0181.

AP-2.21Q, Rev. 1, ICN 0, BSCN 001. Quality Determinations and Planning for Scientific, Engineering, and Regulatory Compliance Activities. Washington, D.C.: U.S. Department of Energy, Office of Civilian Radioactive Waste Management. ACC: MOL.20010212.0018. 
DOE 2002b. Quality Assurance Requirements and Description. DOE/RW-0333P, Rev. 12. Washington, D.C.: U.S. Department of Energy, Office of Civilian Radioactive Waste Management. ACC: MOL.20020819.0387. 


\section{ATTACHMENT A \\ Listing of Safety Evaluation Report Open Items}

The following twenty-eight open items are listed on pages 77 through 79 of Reamer 2000.

1. The staff believes that burnups of spent fuel assemblies must be verified through measurements before their loading into the WP [waste package] for the purpose of burnup credit verification.

2. The consequence criteria for transient and external criticalities are not addressed in the TR [Topical Report]. The DOE must specify if it intends to perform full consequence analyses for transient and external criticality events and include them in TSPA or use some type of criteria for the purpose of criticality control design selection.

3. The DOE needs to provide a modeling approach for igneous-activity induced criticality.

4. The DOE must include the effects of radionuclide migration from an intact fuel assembly through pin-holes and cracks in cladding.

5. The DOE must include criticality margin when comparing $\mathrm{k}_{\mathrm{eff}}$ values from regression analyses to CL [critical limit] values.

6. The DOE must present an approach for developing the criticality margin.

7. The DOE must demonstrate the adequacy of using one-dimensional calculations to capture three-dimensional neutron spectrum effect in their point-depletion calculations or use two/three dimensional calculations for determining the neutron spectra during the depletion cycles to be used in the depletion analyses.

8. The DOE needs to use the cross section data corresponding to the temperature for the WP [waste package] or critical benchmarks.

9. The DOE must include the cross-dependency of configuration parameters for $\mathrm{k}_{\mathrm{eff}}$ regression equations.

10. The DOE must provide the technical basis for the correction factors developed for boron remaining in the solution.

11. The DOE is required to develop an acceptable methodology for establishing bias and uncertainties for the isotopic depletion model. 
12. The DOE needs to establish the bias and associated uncertainty regarding the analysis or model, keeping track of the isotopic inventory loss, through cracks or pin-holes, within intact spent fuel assemblies.

13. The DOE should address the types of criticality uncertainties and biases, which is based on ANSI/ANS-8.17 [ANSI/ANS-8.17-1984], presented by the staff in this SER [Safety Evaluation Report].

14. The DOE must include a multi-parameter approach in its bias-trending analysis.

15. The DOE is required to include the isotopic bias and uncertainties as part of $\Delta \mathrm{k}_{\mathrm{c}}$, if not included as isotopic correction factors.

16. The DOE must present a validation methodology or work scope for external criticality models.

17. The DOE should subject the method used for extending the trend to the procedures defined in ANSI/ANS-8.1-1998, C4(a) and C4(b).

18. The DOE must verify and validate the regression equation or look-up table for all ranges of configuration and WF [waste form] parameters affecting $\mathrm{k}_{\mathrm{eff}}$.

19. The DOE is required to include all uncertainties and variabilities introduced by the regression equation or look-up table.

20. In developing the methodology for steady-state criticality consequences, DOE must consider other types of moderators, especially with respect to external criticality.

21. The DOE must also consider the loss of soluble neutron-absorbing isotopes through pin holes and cracks in the spent fuel cladding, and its effect on steady-state criticality consequence.

22. The DOE must also include other types of steady-state criticality consequences, especially with respect to internal criticality, in its consequence analysis approach.

23. The DOE needs to develop and present for acceptance, the modeling approach for an external steady-state criticality consequence.

24. The DOE must develop and present a request for approval of a methodology for transient criticality consequence.

25. The DOE needs to develop and present, for NRC acceptance, the modeling approach for transient criticality consequence.

26. The DOE needs to develop a validation approach for the power model for steady-state criticality consequence. 
27. The DOE must develop a validation approach for a transient criticality consequence model.

28. The DOE should describe the interface between Figure 1-1 of the RAI responses and the TSPA criticality risk analysis.

\section{Reference:}

ANSI/ANS-8.1-1998. Nuclear Criticality Safety in Operations with Fissionable Material Outside Reactors. La Grange Park, Illinois: American Nuclear Society. TIC: 242363.

ANSI/ANS-8.17-1984. Criticality Safety Criteria for the Handling, Storage, and Transportation of LWR Fuel Outside Reactors. La Grange Park, Illinois: American Nuclear Society. TIC: 231625 .

Reamer, C.W. 2000. "Safety Evaluation Report for Disposal Criticality Analysis Methodology Topical Report, Revision 0." Letter from C.W. Reamer (NRC) to S.J. Brocoum (DOE/YMSCO), June 26, 2000, with enclosure. ACC: MOL.20000919.0157. 


\section{ATTACHMENT B \\ Listing of Model Report Key Technical Issue Agreements}

The following three Key Technical Issue (KTI) Agreements were issued as a result of technical exchange meetings between the NRC and DOE (Reamer and Williams 2000). Each of the listed KTIs is related to the development of the model reports. It should be noted that the "NRC Comment" and "DOE Response" text is identical for each of these three KTI Agreements. However, RT 4.03 and ENFE 5.03 differ from CLST 5.04 in that CLST 5.04 encompasses all model reports and their various revisions whereas RT 4.03 and ENFE 5.03 pertain only to those model reports dealing with the postclosure criticality analysis methodology external to the waste package (i.e., the near-field and far-field environments).

\section{KTI Agreement CLST 5.04}

NRC Comment: Provide the list of validation reports and their schedules.

DOE Response: DOE stated that the geochemical model validation reports for "Geochemistry Model Validation Report: Degradation and Release" and "Geochemistry Model Validation Report: Material Accumulation" are expected to be available during 2001. The remainder of the reports are expected to be available during FY 2002 subject to the results of detailed planning and scheduling. DOE understands that these reports are required to be provided prior to LA. A list of model validation reports was provided during the technical exchange and is included as an attachment to the meeting summary.

\section{KTI Agreement RT 4.03}

NRC Comment: Provide the list of validation reports and their schedules.

DOE Response: DOE stated that the geochemical model validation reports for "Geochemistry Model Validation Report: Degradation and Release" and "Geochemistry Model Validation Report: Material Accumulation" are expected to be available during 2001. The remainder of the reports are expected to be available during FY 2002 subject to the results of detailed planning and scheduling. DOE understands that these reports are required to be provided prior to LA. A list of model validation reports was provided during the technical exchange and is included as an attachment to the meeting summary. 


\section{KTI Agreement ENFE 5.03}

NRC Comment: Provide the list of validation reports and their schedules.

DOE Response: DOE stated that the geochemical model validation reports for "Geochemistry Model Validation Report: Degradation and Release" and "Geochemistry Model Validation Report: Material Accumulation" are expected to be available during 2001. The remainder of the reports are expected to be available during FY 2002 subject to the results of detailed planning and scheduling. DOE understands that these reports are required to be provided prior to LA. A list of model validation reports was provided during the technical exchange and is included as an attachment to the meeting summary.

\section{References:}

Reamer, C.W. and Williams, D.R. 2000. Summary Highlights of NRC/DOE Technical Exchange and Management Meeting on Subissues Related to Criticality. Meeting held October 23-24, 2000, Las Vegas, Nevada. Washington, D.C.: U.S. Nuclear Regulatory Commission. ACC: MOL.20001208.0097; through; MOL.20001208.0110. 